\title{
Information (and library) science at City University London; 50 years of educational development
}

\author{
Lyn Robinson and David Bawden \\ Department of Information Science, City University London, London, UK
}

\begin{abstract}
.
The development of education for information and library science at City University London over a 50-year period is described in this article. The development of the Masters course in Information Science, and the later equivalent courses in Library Science and in Information Management in the Cultural Sector are described in detail, together with shorter-lived Masters courses in pharmaceutical and health information. The rationale for changes to the courses, and the influence of the professional and educational contexts, are analysed. Issues emerging from this analysis are discussed in seven themes: the nature of the discipline; the library/information spectrum; the student group; the academic/professional balance; curriculum design; local and global issues; and teaching methods. The discussions of the courses are set in the wider context of changes in library/information education over the period in the UK and worldwide.
\end{abstract}

Keywords: education

\section{Introduction}

This paper describes the development of City University London's Masters courses in Information Science and associated subject areas, and relates their development to changes in the perceptions of library/information disciplines, professional issues, and in the educational and institutional environment. It also links these issues to the wider context of library/information education through the literature, although no attempt at a comprehensive analysis of the very extensive literature of library/information education is attempted; for examples of such reviews over the period considered, see Saracevic [1], Grogan [2], MacDougall and Brittain [3], Wood [4], Um and Feather [5] and Mezick and Koenig [6].

The paper focuses on the City's MSc in Information Science, and on closely related courses of what is now the university's Information Studies Scheme, as this course has been in existence for

Correspondence to: Lyn Robinson, Department of Information Science, City University London, Northampton Square, London EC1V 0HB,UK. Email: lyn@soi.city.ac.uk

Journal of Information Science, 36 (5) 2010, pp. 631-654 (C) The Author(s), 2010. Reprints and Permissions: sagepub.co.uk/journalsPermissions.nav, DOI: 10.1177/0165551510383086 0 
the whole 50-year period considered. The paper also emphasizes more recent developments which have not been described in earlier papers.

There are few similar examples of detailed analysis of the development of particular courses; one example is Flood's study of the origins of an information science programme at Drexel University [7].

After giving an annotated account of the chronological development of teaching in this subject at City, a series of themes are then discussed, drawing out general issues of education for the information sciences. First, however, a brief consideration of the nature of the academic institution hosting the courses is needed, as this has had a strong influence on their development.

\section{The institution}

The nature of the university as an institution has greatly influenced the way the subject has developed. Its central London location brings the advantages and disadvantages of the metropolitan setting; in practical terms, this has meant, for example, that the course has always made extensive use of visiting practitioner lecturers, many of whom are only a short walk away. It has similarly meant that we have had no pressure towards providing distance learning, since this does not take advantage of the centrality, and associated expense, of our location.

Originally a College of Advanced Technology, founded in 1896 to providing vocational training for the 'useful trades' located in the 'City fringe' area of London, such as clock-making and spectacle making, City developed into a mainly technically-based university. From this, it developed into its current status as the self-styled 'university for business and the professions', emphasizing subjects such as law, business, management, journalism and informatics. This has meant that there has been a strong institutional pressure for developing vocationally relevant curricula, and for having all courses accredited by the relevant professional body.

The professional nature of the university has one negative side, from the perspective of library/ information teaching. The university does not have many of the traditional academic departments to be found at more traditionally organized universities, and with whom links and partnerships for teaching and research might have been made; the lack of a medical school, and of departments covering disciplines such as history, languages/area studies, pharmacy and, in recent times, chemistry and physics, are examples.

Traditionally, the university has encouraged, in all subject areas, a high proportion of mature, parttime, postgraduate and overseas students; this profile has certainly been reflected in the library/ information teaching.

Teaching of these subjects was originally provided by the Centre for Information Science, which later became the department of the same name. It is the only academic library/information department in the UK to have retained its name unchanged since its establishment, and also the only such department to have run a course entitled 'Information Science' since its inception [8].

\section{Chronology}

We now consider the chronological development of the City courses, in four phases:

- the early years, from 1961 to the late 1980s;

- the modernization of the course over the next decade;

- the processes of modularization and re-modularization from 1996;

- the latest restructuring from 2008.

\subsection{The early years}

Teaching of this subject at City University London was inspired by Jason Farradane, one of the founding fathers of information science in the UK [9]. One issue which has been present since the 
earliest times, and has never really been settled, is whether information science is a 'science of information' or a way of dealing with 'scientific information'; Farradane himself seems to have been unclear on this issue $[10,11]$.

The establishment and the early years of information science education at City have been described by several authors [12-17]. This began in January 1961, with a two-year evening course, at what was then still the Northampton College of Advanced Technology. This led to the award of the Certificate of the Institute of Information Scientists, based on a syllabus agreed by the Institute in the previous year [18]. Professional body accreditation was therefore integral to City's courses from the start. Accreditation from the then Library Association was not sought, and the City courses have always had a reputation for being somewhat dismissive of 'traditional' library issues with Farradane [12, p. 261] noting that the course '[assumed] the distinction of information science from librarianship'. This is one respect in which times have definitely changed, although we might note that the originators of the courses envisaged all of library/information work as 'a complete spectrum from the public library to the researcher reading in the library' [18 p. 74].

The Institute's syllabus had three main sections:

- information techniques (the largest), comprising: storage; collection, collation and retrieval; reproduction; dissemination;

- the flow of information, comprising: resources and media; information flows in various environments; copyright, patent, and trademark law, and other legal issues; administration and management of information departments;

- language, writing and editing, comprising; report writing; reviewing; abstracting and indexing; editing; translating.

This was interpreted at Northampton College into a two-year course, with attendance on two evenings a week. In the first year, one evening each week was devoted to sources of information, while in the second year one evening was devoted to classification and indexing, all other topics being spread throughout the remaining time [18]. This emphasis on information resources, and on the organization of information for retrieval, has persisted throughout the life of the City courses, and may be regarded as the first de facto definition of a 'core' for the subject.

A full-time one-year course leading to the award of a College Diploma was started in 1963, and a one-year full-time Masters in 1966, when Northampton College gained university status. The evening courses were abandoned in 1969, and replaced by the pattern which has remained largely unaltered to the present day: a full-time one-year Masters course, with a two-year day-release parttime Diploma with the possibility of subsequent upgrade to Masters; both qualifications accredited by the relevant professional body, at that time the Institute. City University has always been, for library and information science, a postgraduate provider; as noted later, the one proposal for an undergraduate course was not put into practice.

Applicants for the full-time courses were required to have a degree, and this was preferred for the part-time courses, though alternative qualifications were sometimes accepted. Again, this pattern has remained largely unchanged.

The syllabus was organized around:

- information storage and retrieval;

- gathering and dissemination of information;

- legal and commercial aspects;

- administrative aspects;

- foreign languages.

The Masters course also included an evaluative literature survey project, and a dissertation; completion of these aspects allowed students to 'convert' a Diploma into a Masters qualification. Practical work was included in all aspects of the courses.

Over time, the scope of the courses broadened, so that social science graduates, as well as those with degrees in science and engineering were admitted. Nonetheless, the City courses remained 
very much focused on fitting graduates for roles in scientific, technical and medical information settings, as was also the case for a closely equivalent course at Sheffield University [13, 19-22]. This distinction, fitting the view of the subject espoused by Farradane, was suited to the professional context and job market of the time [23]. However, it was already being noted that the methods of information science, understood as Farradane's 'science of information' could be relevant to subjects other than the scientific [24].

Incremental change to the course content progressed over the following years, in the rather ad hoc manner possible before the modularization and academic quality of the present day. The course had its first formal review in 1973-4 and the following year electives in biomedical and pharmaceutical information and in financial, legal and commercial information were introduced, at the expense of a compulsory course in German [16].

In the main these changes, and others made later, responded to changes in the professional and economic environment [25] and, in particular, to the increasing significance of information technology [26]. Another influence was the replacement of the old curriculum of the Institute of Information Scientists by its set of criteria for information science [27]. These had 13 sections:

- knowledge and its communication;

- sources of information;

- organization of information;

- retrieval of information;

- dissemination of information;

- management of information;

- data processing;

- research methods;

- mathematics;

- linguistics;

- foreign languages;

- advanced information theory and practice;

- scientific and philosophical aspects.

The overall result of these influences was to cause the course content to expand considerably. By 1984, the core courses were complemented by five electives of which students could take between one and three:

- science and technology information;

- biomedical and pharmaceutical information;

- legal and community information;

- business information;

- research and development.

\subsection{Modernization}

A major review of City's information science teaching took place in the late 1980s. As well as the factors noted above, the Department of Information Science had initiated two new courses: a small Masters course in Librarianship and Arts Administration, and a larger course in Information Systems and Technology. Both were joint courses with other departments of the university, and involved joint teaching; such interactions were to have significant effects on information science teaching from this date on. Another influence was institutional in nature. City University had been deliberately created without a faculty or school structure, but this was retrospectively imposed, and the Department of Information Science was incorporated into a School of Informatics, along with the departments of computer science and business computing. This location tended, inevitably, to reinforce an emphasis on the technological aspects of the subject in the department's teaching and research; though this was, to a degree, resisted by some of the staff, creating interesting academic tensions. 
The restructured Information Science course had a much more granular structure, with eight core courses and a choice of two electives from 13 available, though not all were offered every year.

Core courses were:

- information industry and information resources;

- computers and communication technology;

- information management;

- information retrieval;

- communication skills;

- legal and policy aspects;

- research methods;

- evaluative report.

Electives (two taken (though not all were offered every year)) were:

- systems analysis and design;

- programming, software and hardware;

- current research topics;

- patents and innovation;

- legal information;

- business and financial information;

- social science information;

- community information;

- medical information;

- pharmaceutical information;

- information for science-based industries;

- marketing and public relations;

- records management;

- dissertation.

The course was not modularized, so that its components were not consistent in terms of time allocated or level of study. Assessment was largely by formal examination, with subjects distributed across several papers; it was therefore possible to graduate without attempting any assessment in some subjects, a prospect anathema to current educational thinking. There were also substantial coursework assignments or practical exercises for information retrieval, communication skills and the evaluative report, and for the dissertation project.

Teaching was largely by traditional lectures, and the full-time and part-time groups were, for the most part, taught separately. This gave the advantages of small homogenous groups, at the expense of repeated sessions.

The large number of options, although a major attraction of the course, and still remembered fondly by ex-students, led to timetable clashes, so the choice was never as great as it appeared. There was also a degree of overlap in content. With hindsight, it can be seen that there were too many electives at this stage, the starting point of a swinging pendulum, with no ideal resting point.

A proposal was made at this stage for an undergraduate course in the library/information area. All the available evidence suggested that 'pure' library/information undergraduate courses were unsuccessful, and planning focused on a course in the health information speciality [28]. However, the university's strategic interests changed, and the course was never launched. Since that time, although academics in the Department of Information Science teach modules in aspects of information management on undergraduate courses elsewhere in the university, the library/information area has remained entirely postgraduate.

\subsection{Modularization and re-modularization}

In 1996, the Information Science Masters programme was modularized, along with the rest of the university's courses, in keeping with the general trend in UK academia. Although the basic structure 
of eight core and two elective units was kept, they were rationalized to have a common academic level, and the same amount of class time and student effort.

The content was relatively left unchanged, although some material was moved between different course units, and the number of electives was reduced. The 'evaluative report', a literature analysis assignment which had featured in the course since its inception, was dropped, largely because with a move to assessment by coursework, rather than formal examination - literature evaluation featured in several other aspects of the course.

Two new elements were introduced to the course at this point. An 'independent study' elective catered for students with a particular - typically theoretical or conceptual - interest, not catered for in other parts of the course. And - in response to a perceived disadvantage of modularization, that it made it difficult for students to gain an overview of the subject - a compulsory 'integrative studies' module was introduced. Taught at a late stage in the course, this had no real content of its own, but was designed, through a series of seminars and exercises, to enable students to bring together material from across the course, and appreciate the 'big picture'. This approach - novel so far as we are aware - provoked much interest within the university.

The modularized information science course structure was:

- information technology;

- research, evaluation and communication skills;

- principles of knowledge organization;

- information resources and users;

- information and library management;

- information law and policy;

- information retrieval;

- integrative studies

- two electives (from a choice of about 10);

- dissertation.

Having modules of a consistent size and standard meant that exchanges of material with other courses and the offering of 'bite sized' education became possible, and this tested out almost immediately with the Information Science course. Modules, particularly electives, were shared with other courses within City's School of Informatics. An inter-university exchange was tried, with electives shared with the library/information courses at University College London, the other major provider of postgraduate education in these courses in the London area [29]. Some of the modules were offered as stand-alone continuing professional development (CPD) courses for practitioners, and gained a modest take-up; in a small number of cases, they acted as 'tasters', encouraging the participants to enrol on the full course. This has always been seen at City as the best way for a university department to find a place in the very variegated environment of CPD provision [30].

The nature of the student group on the City courses had changed considerably by this stage. Whereas the 'traditional' intake were required to have degrees or equivalent in scientific or technological subjects, later broadened to include the more quantitative social sciences, by the mid-1990s the majority of applicants were from a much wider background, including the humanities, vocational subjects, and 'softer' sciences. In this respect, City was perhaps merely catching up with the trend; a decade earlier, Smith [31, p. 38], commenting that of the UK departments only City and Sheffield showed a preference for science graduates asked 'why are the science and business graduates not attracted to information courses?' The answer, and the change in the City intake, reflects a variety of factors, but most simply the decline in the number of UK students taking first degrees in science and technology, and the decline of UK science-based industry as a source of employment. The course content, and teaching methods, adapted over time to deal with this.

A more drastic change was then made, in line with the university's policy to encourage the setting up of new courses, aimed at specialist student requirements, but taking advantage of modularization to provide efficiencies by sharing course content. The Department of Information Science set up four new masters courses, while retaining the Information Science masters: 
- Library and Information Studies. This aimed to provide a course aimed at those many actual and potential applicants interested specifically in library, rather than information, work. While not really such a change from the status quo (many graduates from the Information Science degree, then as now, went on to work in libraries, and a small part-time 'Alternative Programme for Librarians' had been run during the 1980s), the fact the City were now using the 'L-word' caused some surprise in the profession.

- Pharmaceutical Information Management. A highly specialized course, launched at the request of, and in conjunction with, a small professional body, the Association of Information Officers in the Pharmaceutical Industry. This had a number of distinct features, including a high proportion of practitioners as teachers of whole modules, and the concentration of teaching into 'block' modules of five consecutive days [32].

- Two courses run jointly with City's Arts Administration department, aiming at information management in arts centres, and in museums and galleries, respectively. These can be seen as a kind of replacement for the earlier, and long since discontinued, course in Libraries and Arts Administration, showing how ideas come back into fashion.

As will be seen below, these new courses had varying degrees of success.

A further restructuring was made after only four years, again to meet the requirements of central university policy. In order to ensure compatibility with the developing Bologna process for harmonizing European higher education [33-36], to give reliable European credit transfers values (ECTS) to our courses, and to provide consistency across the university, it was decided that all of the university's modules should carry multiples of five credits. In practice this meant that the library/ information courses had to be restructured from 10 modules to eight, each carrying 15 UK credits, equivalent to 7.5 ECTS and roughly 4 US credits. This structure has remained constant to the present and - as it is the institution's norm - is unlikely to be changed.

This was largely achieved by repositioning of material between modules, but had two undesirable consequences. The innovative Integrative Studies module had to be abandoned, and has not been satisfactorily replaced. And the number of electives had to be reduced from two to one. When combined with a requirement from the university authorities for rationalization and module-sharing, on efficiency grounds, this meant that we were now offering too few choices of elective, particularly in core areas of library/information science; the pendulum had swung to the other extreme.

Changes were also made to the portfolio of courses, at this stage. The course in Pharmaceutical Information Management, after initially healthy recruitment, had few students, largely due to changes in the environment of the pharmaceutical industry, and the UK health services. It was therefore discontinued, and replaced by a broader-based course in Health and Pharmaceutical Information, taught jointly with City's Centre for Health Informatics. The two courses for the arts and heritage sector proved to be too similar to be run effectively as separate entities, and they were combined into a single course, Information Management in the Cultural Sector.

Teaching methods were affected by the university-wide adaption of an e-learning environment, pioneered in the Department of Information Science. For the library/information courses, this has always been used as an adjunct to face-to-face teaching, rather than a replacement for it; see Mezick and Koenig [6] for a review of the various approaches to use of e-learning in this setting, pointing out the problems of uncritical adoption. There has been no desire at City to introduce a fully distance learning version of the courses, although the system and teaching materials have been used for international professional development courses [37]. Other international links came about through the formation of international exchange programmes for students and lecturers, through the European Union's Socrates/Erasmus programme: such links were formed with Ljubljana University (Slovenia), Vilnius University (Lithuania) and Charles University Prague (Czech Republic).

A further, and significant, change came about in 2002, when the Institute of Information Scientists merged with the (British) Library Association to form the Chartered Institute of Library and Information Professionals (CILIP). All the City courses were therefore accredited by CILIP from this date, and the curriculum matched against CILIP's Body of Professional Knowledge (BPK) [38-40]. The BPK specifies the core concepts required to be covered for accreditation under the following nine headings: 
- information;

- knowledge;

- documentation;

- conceptual structures;

- collection/information resource;

- user/client;

- subject context;

- professional context;

- transferable skills.

Not, perhaps, so different in broad brush terms from the original Institute curriculum.

\subsection{Restructuring}

Library/information education at City went through its latest, and for now final, restructuring in 2008/9. The Health and Pharmaceutical Information course was closed, a victim of both a general trend for applicants to prefer 'generic' professional training in a time of economic uncertainty, and of specific issues within the UK health services and healthcare industries.

Of the other courses, Library and Information Studies had immediately become, and has remained, the largest of the library/information courses; it was renamed Library Science, to give a clear indication of its focus and distinction from other courses. Information Science, and Information Management in the Cultural Sector, both maintained good recruitment.

These three courses have been formally linked in an Information Studies Scheme, with a common course structure, several shared modules, an ability to change courses, and common marketing and other processes. The current structure of the Information Science course is:

Core:

- library and information science foundation;

- data and information technology and architecture;

- research, evaluation and communication skills;

- information management and policy;

- information resources and organization;

- information retrieval;

- information domains.

An elective, typically chosen from:

- libraries and publishing in an information society;

- web applications design;

- data visualization;

- open source software;

- independent study;

- dissertation.

The only significant change in content is our introduction of an Information Domains module, a way of presenting subject specialist information, and involving a study of information resources, systems and users in numerous subject areas, given coherence by Hjørland's concept of domain analysis [41, 42].

The Library Science course differs in two core modules, and offers a different range of electives, including several from cultural and heritage areas. The Information Management in the Cultural Sector course offers a choice of modules focusing on information resources, organization and retrieval or on information management and policy, with half the course content provided by the Department of Cultural Policy and Management. The scheme is therefore very much based on the 'spectrum' model of the information sciences, from the scientific and technological to the cultural and heritage, and on a conceptual model of the nature of the area [10]. 


\section{Issues}

We now move to a consideration of the issues which have emerged from this chronological account, organized in seven themes:

- the nature of the discipline;

- the library/information spectrum;

- the student group;

- the academic/professional balance;

- curriculum design;

- local and global issues;

- teaching methods.

\subsection{The nature of the discipline}

To provide a coherent academic course in any discipline, it is necessary to understand what that discipline is. As we have seen, there has been some uncertainty, from the earliest stages, as to whether an information science course deals with a science of (all) information or with the handling of (specifically) scientific information. This has practical implications both in the content prescribed for the course, and in the students recruited to it; a course in scientific information will require students who already have a high degree of scientific literacy.

It seems clear that the City course initially followed the 'scientific information' model, under the influence both of the Institute's criteria, the perceived vocational needs of the students, and the preferences of funders. Although theory has always been a significant underpinning of the City courses, there was never an attempt to make them into the kind of purely academic 'science of information' courses, of the kind run for a short time by B.C. Brookes at University College London [43].

Over time, this model has changed, most notably in the fact that, during the past decade, only a small minority of City students have had scientific or technical qualifications from a first degree. The model has moved to be that of regarding information science, and library science, as methodical (not necessarily quantitative or technology-heavy) studies of information in a variety of domains, not necessarily scientific. The science in information science is Wissenschaft rather than Naturwissenschaft. Indeed, we have some sympathy with the view that information science is really a form of liberal art $[44,45]$, and encourage the students to study quite widely in related subject areas. Nonetheless, we regard an exposure to the details of subject-specific information as an essential for studies in information science; hence the recent inclusion of Information Domains as a core module. We also regard familiarity with relevant information technologies as non-negotiable for any library/information student, and such teaching, as always, formed a part of the core courses.

In order to give coherence to what may have been in the past a rather ad hoc process of curriculum design, we think it important to base the design of teaching around a clear conceptual model of the subject area [10]; this has brought benefits in the latest course redesign.

\subsection{The library/information spectrum}

As will be clear from the account above, course design at City has proceeded on the basis that there is a spectrum of 'sciences of information'. This is not, it should be made clear, a universally accepted view. There are those who would argue that librarianship and information science are distinct and even inimical to one another; see, for example, Gorman [46]. This has been further explained, for our purposes, as a multidisciplinary field of study, with the central concept of human recorded information, with an intellectual core of information science underpinning several practical disciplines, including librarianship and information management [47], and further explained as the study of the communication chain, through the methods of domain analysis [10]. With these conceptual models as a base, courses can be rationally planned to cater for interests in various parts of the spectrum, since it is too broad in scope for any single course to cover it adequately. 
It is plain that City's coverage of the spectrum has increased markedly, with the introduction of courses in library science and in cultural sector information. Even so, the City 'brand' still retains a technology/scientific/subject-specialist image, though it is much more mainstream than it was when a guide to library schools by the Association of Assistant Librarians [48, p. 24] could say that 'the material covered is directed towards the work of an information department in an industrial firm, and because of this the course is not directly comparable to other library schools'. In terms of the typology of library schools proposed by Cronin [49], it seems fair to say that City has adapted from being a 'niche' provider to being more 'broad church'; thankfully, this seems to be the most sustainable posture.

As is also clear from the above, the more specialized courses which have been attempted in the information science area have not met with great success. This is true of similar courses at other UK institutions. This seems to suggest that, particularly in times of uncertainty as to future employment patterns, students will prefer to follow a 'generic' vocational course, rather than one aiming to fit them specifically for one job profile. As it seems that our times are likely to become more, rather than less, predictable, the message seems to be that a smaller number of broadly defined courses is better than a larger number of niche titles. Changes in content and emphasis are better dealt with by amending the curriculum of established broader courses, rather than creating new ones.

Similarly, we have been able to avoid the pressure some felt from institutions for launching courses in 'hot topics' or to satisfy a perceived immediate demand from the profession for training in issues of the moment. There are ways of dealing with such needs; we have found electives within established courses, which can also be offered as CPD components, to be one good solution, and some examples of topics which come in and out of favour are given below. Setting up new academic programmes is rarely appropriate.

It is also worth noting the way in which course subjects fall out of fashion, and then come back in again, as witnessed by the success of the cultural sector information course, following on from the earlier Librarianship and Arts Administration offering. The message here may be to keep faith with courses passing through a dip in popularity.

\subsection{The academic/professional balance}

Grogan [2, p. 12] reminds us, in the context of education for librarianship, that 'Underlying much of the unease between the profession and the library schools over the last hundred years has been the potential conflict between theory and practice'. There is still a continuing debate about the nature of academic courses in the information sciences, and whether these should be seen as promoting vocational training, developing a research-based professionalism, or establishing an academic discipline; see, for example, Audunson [50], who argues for a pluralistic approach, and Brine and Feather [51], who point out that there is typically less agreement about what practical skills are needed by graduates than there is on the necessary knowledge and understanding. A discussion forum reported by Bawden [52] suggested that there might come to be a three-tier provision: 'i-Schools', providing a high-level, broad and non-vocational education; 'library schools', providing a more strictly vocational education, aimed at particular job roles, and tightly controlled by accrediting bodies; and training for specific skills and competences provided through CPD, particularly via e-learning. In as much as this model proves valid for the future, City is firmly in the first category, though we have never sought to join the official i-Schools movement, with its attendant issues and controversies [6, 53-55].

The City courses are, and have always been, regarded as providing primarily academic qualifications, rather than simply professional training. We agree with the views of a UK government report [56, p.29] that 'a degree or diploma in library and information science can legitimately be seen as an acceptable academic and intellectual training in itself, every whit as respectable as a degree in history or biology or law, and fitting the graduate for a very wide range of non-specialized employment'. We are further constrained by the requirements of the UK's higher education Quality Assurance Agency, who require that a majority of the teaching on a Masters course should be at an appropriate 'M-level', ruling out any substantial proportion of skills training in such a course. 
We are clear that what is offered by courses such as City's should be education rather than training, long-term understanding and attitudes rather than short-term skills. We relate to the comments of a practitioner reported nearly three decades ago by Cronin [57, p. 6]: 'How we employers dislike "trained" people from the library schools. We know how to train. What we have no time to do is to educate. We can do the details, not the big picture'. In the present economic environment, many employers may feel that they now have no time to train: but the solution to this must lie in CPD, not in an initial academic course. If we believe in the often-quoted formula 'teach knowledge, train skills, exemplify attitudes', then City's focus has been, and remains, primarily on the first, secondly on the third. This means, as we note below, that for topics such as cataloguing and library management, we focus on imparting a general understanding of the concepts and issues, enabling specific skills to be gained when needed, in the workplace or through CPD. We agree with Maurice Line [58, p. 30] that 'skills not only can but must be picked up in practice', and that formal education must focus on knowledge and understanding.

Of course, as noted, a number of factors, not least City University's view of its main institutional purpose, as well as the views of accrediting bodies, have led to the information science courses at City being to an extent vocational, rather than wholly academic, in nature. Nonetheless, the courses have always followed the views expressed by Robertson [43] that even a vocational course in this area should have a firm academic basis. This is, if anything, more important than ever, in an environment where there are many more resources, media and technologies to deal with.

This is achieved by ensuring that practice and theory are presented together, and that detailed coverage of practical issues is based on a previously encountered conceptual framework, as, for example, in the current teaching of reference and information services [42]. We intend that the understanding gained on the course will serve graduates well for many years to come. In an environment of constant change requiring a flexible response, and movement between sectors and into 'non-traditional' roles [59, 60], that cannot be achieved by purely practical training; as Roggema-van Heusden [61, p. 98] expresses, it is important 'to respond aptly to changeable professional situations ... to acquire new knowledge and skills continuously'. Our aim is that graduates will be equipped to ask the right questions in their future careers, rather than that we provide them with a set of (rapidly outdated) answers. To this end, we find one of the university's current strategic aims - that all teaching be directly and explicitly underpinned by research and scholarship - to be helpful. The City Information Science department has had a strong emphasis on research since its earliest days; all members of staff are active in research and scholarship, and the department has scored well in the various national research assessment exercises. City's information teaching is therefore explicitly research, in a manner similar to departments with a similar ethos [62].

The City courses have never offered work placements as an integral part of study, unlike most other European library/information departments [63], as it has never been thought to be a good use of time in a crowded curriculum, despite the benefits from such arrangements at other institutions $[64,65]$. Virtually all students have some relevant experience before the course, though it is no longer the norm as it used to be; pre-course experience was never an absolute requirement at City, as it was at most equivalent institutions, and the definition of 'relevant experience' has always been broad. This approach is ever more justified as 'information work' covers a growing part of all workplaces.

The majority of students, full-time as well as part-time, undertake paid work during their studies. We also offer assistance for students who want to work as volunteers to gain experience, and many do so. This flexible approach has proved more valuable than a formal placement scheme.

Some students also choose to undertake workplace projects for course assignments and, particularly, for the dissertation project. Each year a number of projects are published as journal articles; some are academic studies, others are examples of practically useful projects. This seems to us to be a particularly good example of a successful linkage of the professional and the academic, providing that the potential problems with such arrangements are guarded against [66], and may go some way to overcoming the lack of interaction between library/information research and the practitioner, identified decades ago [67]. 


\subsection{The student group}

The nature of the student group has changed over the years; the move away from a scientificallyqualified intake, even when Information Science was the only course on offer, has already been noted. This situation causes some problems, as noted by Rosenberg [68], some years before City had to deal with the problem. One issue is the need for a reasonable level of numeracy and basic statistics, stated to be essential for all library information work by Line [58] in 1983, and now arguably more so, and which are less likely to be found in those without a previous scientific or technical education. However, as a first professional masters, rather than the advanced masters more common in continental Europe - see, for example, Ingwersen [69] - all the students are new to the subject, and, again as noted above, with varying extent of professional experience, all the subject matter must be covered from basics. The good news is that there is evidence to suggest that the lack of a relevant first degree need not be a barrier to long-term success in, for example, health information work [70].

City's library/information students have always been an entirely postgraduate group since the only serious attempt at launching an undergraduate course was abandoned. This is in line with the British experience, which has shown over several decades that undergraduate courses in this area recruit poorly, and produce low standards, so that the postgraduate route is the norm [5, 13, 71-73]. In continental Europe, undergraduate education in the subject has always been more usual [68, 74]. Recent experience from the USA suggests that rising demand for college studies may offer new opportunities, at least for minor or subsidiary library/information contributions to undergraduate degrees [75]; perhaps the same will be true of the UK in the near future. Um and Feather [5] have noted an increase in UK undergraduate courses in aspects of information management, though not taking a library/information perspective, nor accredited by CILIP.

The numbers on the City library/information courses have remained remarkably stable over a considerable period. In 1981, there were 100 students, with seven academic staff. In 1986, there were 96 students, plus 44 students on other courses in the department, still with seven staff [56]. In the academic year 2009-10, there were 107 library/information students, plus 79 on other courses, with eight full-time staff equivalents. The unfavourable change in staff-student ratios over the period is common to all of British higher education, while the staffing numbers put us in the $27 \%$ of European library/information departments with less than 10 full-time equivalent staff [63]. We also have the added challenge of an increasingly smaller proportion of staff primarily devoted to the library/information side of City's teaching.

We have retained full-time and part-time modes throughout almost all the lifetime of the City courses. Part-time attendance, with the exception of the block modes used for the Pharmaceutical Information Management course with mixed acceptance by students, has been by traditional one day per week 'day release', still an acceptable norm for library/information employers.

The old pattern of full-time students attending classes five days a week, and doing little or no paid work, while part-time students were in full-time employment, has largely been replaced by a much more 'mixed economy', with the full-time and part-time distinction referring to the time taken to complete the course, rather than being indicative of work status. A short-lived introduction by the institution of a specific 'flexible' mode of study, with some face-to-face attendance supported by e-learning rather missed the point that all students are now de facto flexible attendees.

A concentration of teaching for all students into two days of the week, apart from allowing fulltime students to undertake significant paid work - a necessity in the current climate of student debt - has opened the course to students living in continental Europe, with access to international trains or low-cost airlines, and we currently have such students commuting from France and Denmark.

With the exception of one early survey [14], there have been no large-scale surveys or analyses of the employment and subsequent careers of City library/information graduates, of the kind carried out at other institutions [see, for example, 76, 77]. Informal sampling suggests that employment-first destinations have remained largely stable over the lifetime of the course; roughly $50 \%$ of the graduates go into information management, special libraries or subject specialist roles; $25 \%$ into general library work; and $25 \%$ into a wide range of information-related occupations, including research, consultancy, publishing, web-design, training, museum work and marketing. With addition of the 
library science and cultural sector courses, the first and third of the categories have become more significant. The 'alternative career' possibility has always been more the norm for City graduates than appears to be the case elsewhere [78].

\subsection{Curriculum design}

The City information courses were originally designed from scratch in the 1960s. Since then, modification of the curriculum has been a process of incremental change, with four factors acting as both stimuli and constraints: past custom and practice; the requirements of the accrediting body; the requirements of the institution and the national educational quality control agencies; and the views of students, and potential students, alumni and employers. Kinnell [79] and Huckle [80] analysed the effect of these forces on library/information curriculum design in the UK, and Mezick and Koenig [6] gave a worldwide review

The last factor has been taken particularly seriously; examples are a market research survey of professional opinion before the design of the Pharmaceutical Information Management course [32], a survey of employer opinion of requirements for teaching knowledge organization [81], and a recent survey of alumni and employer experience through a recruitment agency.

Change has therefore never been radical; although, as noted above, there have been frequent reviews and restructurings, we have never had the luxury of being able to design, or redesign, the curriculum from scratch, based on a conceptual analysis, as have other educators; see, for example:

- Ingwersen [69] using a domain and study element analysis of the subject;

- Lancaster [82] using an approach based on the information transfer cycle;

- Grover and colleagues [83] using and theory and applications matrix;

- Roggema-van Heusden [61] using a competences framework;

- Missingham [84] using a skills framework;

- Wilson [85] using a 'foundation field' approach; see Bronstein [86] for an analysis of current curricula using this approach

We have, however, as noted elsewhere, used several models and conceptual frameworks to guide curriculum development. This is particularly necessary in order to convert the requirements of accreditors into practical curricula; Farradane [12] noted in 1970 that the Institute's curriculum had to be 'interpreted', and the same is certainly true of CILIP's BPK [40]. In particular, such models can be used to try to determine the balance of 'core' and optional material.

The place of the department in the institutional academic structure has not had a great influence on the curriculum. Though located in a School of Informatics, and therefore with closest links to computing and IT departments, most teaching collaboration has been with the City's Schools of Arts and Social Sciences, as evidenced by the provision of electives in cultural and arts topics for the library science course; formal interaction with the computing departments is limited to some teaching on digital library topics. Indeed, a certain independence from the local academic structure may be expected, given the wide variety of organization situations of European library/information departments, including links with computing/IT, humanities, social sciences, business, and communications/media shown in a survey [63]. If departments allowed their local situation to determine the curriculum, there would be little consistency or coherence in the discipline.

Considering the City curriculum over time, a remarkable stability is evident. The central topics information resources; information organization; information retrieval; information management; legal issues; technology applications - remain, albeit in different combinations, and clearly with different detailed content. The variation over time is in the more peripheral and specialized areas, typically appearing as elective modules. The various models and frameworks noted elsewhere have helped to decide which material should be compulsory and which optional.

Considering central topics brings us the vexed and long-standing [25] question of the 'core' of the library/information curriculum; as Cronin [53, p. 363] reminds us 'the nature of the common core is debated ad nauseam'. Grogan [2] gives a detailed account of views on the core curriculum for library 
education, from the early days of general agreement that it comprised the 'old quadrivium' of cataloguing, book selection, reference and administration. Various commentators have stated that the core is needed [46], is in decline [87], is continually evolving [88], and is growing to include a 'semicore' [88]. It has been variously claimed that the core should be based on human-computer interaction, information literacy, information management, documentation, library management, knowledge management, information society studies, information-seeking and retrieval, and others [see, for overviews, 6, 52 63, 90]. IFLA's guidelines mention 10 'core elements', all broadly expressed [91].

It has been argued, from a basic consideration of the nature of information science as a discipline, that the core of the curriculum can be identified as information retrieval, information seeking and knowledge organization [36, 92]. Another approach to this, due to another of the founding fathers of British information science, Brian Vickery, has been to recognize that there are some fundamentals of human information-related behaviour and of the organization of information, which do not change. It is the business of the information scientist to investigate them, and to show their relevance in whatever information environment they may be instantiated [93]. This also points to information seeking/retrieval/organization as a core, and this has generally been the case at City for the Information Science Masters. For the library-related courses, issues of collection development and management, and the library's place in society, are equally important.

We now mention, briefly, a number of specific topics within the curriculum, and the way in which they are dealt with at City, to exemplify the choices made in curriculum design. Topics may be present in the curriculum in three ways:

- they have a module, or other discrete structure within the course, devoted to them;

- they have a discrete place in the course, less than a module, typically one or more lectures, devoted to them, but appear more widely;

- they have no specific part of the courses devoted to them, but permeate the whole.

Different institutions, and indeed different courses at the same institution, may treat any given topic in any of these ways. It is therefore not satisfactory to compare courses simply by comparing module names, as noted by Borup Larsen [63]. The same is true of comparative studies to determine the skills developed in library/information education [94].

The conceptual basics of the subject have a module - Library and Information Science Foundation - devoted to them. It is never easy to decide whether concepts, philosophical viewpoints, theories, etc. should be treated in isolation, or in the context of some other part of the curriculum. We have chosen to introduce them briefly here, so that the students get a conceptual overview of the whole subject at an early stage, and to return to them in appropriate contexts.

Information technology has always been an important feature of the course, as it has in all library/ information settings, though developing differently according to the situation [95]. Again there is the issue of whether it should be an element in its own right, perhaps tied in to an external IT competence qualification [96], or whether it should be contextualized, with the technology introduced for library/information purposes [97, 98]. At City, the approach has been to provide an initial 'basic concepts' course, developed later in the teaching of, for example, information retrieval [73], and latterly of digital libraries. These topics can cover a variety of content, and may be taught from a variety of perspectives [99-106]. At City, they are presented in a tightly integrated way, starting from the concept of the document, as the basic unit for representation and handling in databases and collections. Topics for inclusion are selected from a series of individual subtopics, identified from a collaborative analysis of the subject area [92].

The information organization area is one whose place in the curriculum has been particularly controversial, for two reasons. First, there has been continuing debate as to whether this area should remain central in library/information teaching, with the suggestions on the one side that it is outdated, and on the other that a unique aspects of the discipline is being pushed aside. Second, there is equally continuous debate as to the extent to which specific skills - particularly those of cataloguing and classification - should be taught in detail, rather than simply a coverage of general issues and principles. For overviews of the debates, see [81, 107-111] 
Information organization, with a particular emphasis on subject analysis, has always been central to the City curriculum, largely for pragmatic reasons of student preference and the requirements of accrediting bodies. More recently, practice has been informed by the analysis of the core of the syllabus, which we argue must include information organization [92], and by a survey of the views of employers and professional bodies [81].

As a result, the topic is taught in one dedicated compulsory module, with specific subject examples and service applications presented elsewhere. Emphasis is firmly on concepts and principles, rather than specific skills. In this, we are in line with the stated preferences of major employers such as the British Library:

What is needed is a principles based approach that looks at resource discovery holistically. Cataloguing has too often been concerned with the minutiae of the inputs ... The curriculum should equip the student with the knowledge to ask the right questions about the resource they are cataloguing or the discovery system they are using [112, p. 11].

\section{And City of London public libraries:}

What [I want] is an intelligent candidate who understands the principles of cataloguing and indexing, and to whom I can therefore easily explain the ways in which we choose to apply them in our own situation. [113, p. 10]

The same debate on importance of skills training has appeared over a long period regarding the place of management in the library/information curriculum [25]. Generally agreed to be an important and central topic, this has been treated in diverse ways within the curriculum [114]. In particular, it has exhibited a rather schizophrenic nature: is it about the management of information per se, and hence focused on specific information-related issues, or about the management of an information department, and includes more 'general topics'. At City, where this has featured since the earliest days of the course, initially under the guise of 'administration', the emphasis in the information management and policy module is firmly on information management, including the management of documents and records, knowledge, collections, etc. and the legal framework which supports it. General management topics do appear here, and elsewhere in the course, often through the contribution of practitioners. However, this involved focusing on concepts and principles, allowing students to see the context and relevance of the topics, as a preparation for practice. There is no attempt to cover the practical detail of budgeting, recruitment, etc. - this is most appropriately dealt with at the time of need, by workplace training, or CPD.

'Leadership' is an aspect of library/information management education much discussed recently [115]. Although, as noted above, City fits within the general 'i-School' form of department, one whose remit has been identified as providing an education for future leaders [52], the course is not aimed at developing leadership capabilities in experienced professionals; as a first professional Masters, it could hardly do so. This is the remit of City's Masters in Information Leadership programme, launched in 2010, and aimed at potential leaders in a variety of information-related professions.

Research methods is the final topic which has been a central part of the City curriculum since its inception. This is a topic now included in virtually all higher level information courses, and is presented in diverse ways and with variable content [62, 116-119]. It is presented at City in a module linked to more general professional issues, and to the communication and use of research findings, with the aim of stimulating the carrying out and use of research by future practitioners, and of promoting reflective practice in general.

Some topics, while maintaining an important and central place in the City curriculum, do not have a discrete part of the course to themselves; the second of the categories noted above. An example is reference and information services, which in many similar courses has a module devoted to it [120]. At City, the subject matter of this topic is spread throughout several modules, dealing with resources retrieval, subject-specific information, etc. [42].

Another such 'spread' topic is the ethics of information research and practice, where an increase in the number and complexity of such issues calls for a greater presence in the curriculum [121-123]. 
This is treated centrally and specifically by sessions in the module dealing with research and professional issues, but occurs in several other contexts on the course.

While, as noted above, the central core of the City course has remained constant over the years, the same is not true of the many specialized topics within it; these have come in and out of favour, and the course structure has adapted to match. The most obvious example is the way in which subject-specialist information has been treated.

A good case of this is business and financial information. At the start of the course, this was a minor topic at best, given the initial focus on scientific information. However, particularly in response to City's proximity to, and links with, to the City of London it developed over time to become a significant, and well-known, part of the course, with its own elective module [124, 125]. However, with the growth of the migration of virtually all information in this domain to digital form, and the massive growth of end-user information services, the significance and popularity of this area for information professionals decreased. This trend was completed by the economic crises of the first decade of the new century, so that now business and financial information have their place in the course mainly as an element of the subject-specialist module. This gives an introduction to the area to all students, and allows those interested to specialize through assignment choice, independent study and the dissertation project; some of the projects are published in the journal literature [126], maintaining the 'academic profile' of the area. An analogous example is media information, which also grew sufficiently in importance to have an elective module of its own during the 1990s. With the increase in end-user access in this sector, and the consequent decline of information services in news and media organizations, culminating in the closure of the Association of UK Media Librarians group after 23 years [60], this topic has been subsumed into the main curriculum, in a way analogous to business information.

The same picture can be seen for health information, which in the past had two elective modules and then a whole course devoted to it. The changing environment and changing student profile has led this subject to be treated in a similar way to business; the academic profile is maintained by staff expertise manifested in textbooks and reviews $[127,128]$.

Other examples of topics which over time moved from an initial relatively small presence in the main curriculum to having a distinct presence in the course at dedicated elective module level, but have now been subsumed into contributions to other course units, are patents [129], community information [130], information society issues, which have themselves been argued as central to the information science curriculum [131], and geographic information systems. This reflects the difficulty, noted above, of fitting a very wide range of subject matter into a crowded syllabus. City's recent approach has been to find means to allow all students to be exposed to the basic ideas, and for those who wish to specialize in the topic to do so, while maintaining our academic credibility in these areas through research and publication.

The third form of presence of a topic in a curriculum is that it may pervade the whole syllabus, without being accorded any specific place. Two examples of this for City are international and historical perspectives. International and intercultural viewpoints are evident, are increasingly more important and are treated in different ways [132]. Unlike many other institutions, City has never offered any specific module in 'international' or 'comparative' library or information science; rather we seek to include an international perspective in all our teaching; it is an obvious help to have a relatively high proportion of international students, often with professional experience in their own countries, and to have our international exchange partners. And, while we do run sessions on the new topic of 'information history' [133], a historical perspective again imbues all our course content; we feel this to be a particularly important perspective, in danger of being lost from the curriculum [134].

\subsection{Local and global issues}

As will be clear, the nature and development of the City information science courses has been influenced by local, national and international interactions. 
Locally, our central London location has influenced us, in terms of easy accessibility by students, precluding the need for distance learning, to practitioner lecturers and to significant libraries, archives, cultural centres and major information centres. We have also worked, to a limited extent, in conjunction with the other three institutions providing masters level library/information education in the London area. A greater degree of cooperation, made difficult by institutional constraints, would be desirable; perhaps it is a pity that the 'London Postgraduate Library School', envisaged by a review group in the 1980s as involving a consortium of academic departments plus the British Library [56], was never seriously considered.

Nationally, the most productive means of ensuring that our courses are in line with best practice elsewhere has been the external examiner system, with City academics taking this role at various times at most of the other equivalent departments in the UK. Though this system may be criticized as a means of quality assurance [135], its value for course improvement is considerable. Other national initiatives, such as the learning and teaching support networks [51] and the system of national subject centres [136] have been of more limited value. Formal collaboration with other UK schools has been very limited, one example being a collaboration with Loughborough to create and evaluate a system for teaching the use of electronic journals [137].

Internationally, the significance of harmonization with the Bologna process has been noted, although, of course, we retain the anomalous position of one-year Masters degrees, against the Bologna norm of two. While, in view of the perennial problem of a crowded curriculum, about which Bottle [16] was complaining as far back as 1976, we would, in principle, welcome a move to a two-year course, economic and resource factors seem to rule this out for the foreseeable future.

International links and exchanges, vital for course development, have been mentioned above. The most important example was City's engagement with a Europe-wide project to attempt to construct a common European curriculum for library and information science [138, 139]. This, and consequent collaboration, led to considerable changes in our teaching, particularly in areas of information retrieval and information seeking [99, 100, 140]. A more limited international collaboration informed our teaching of digital library issues [106].

Nonetheless, the extent of City's international cooperation and coordination remains limited; a reflection, perhaps, of a general and long-standing mixed pattern within European and worldwide library/information education [6, 35, 141, 142]. Regrettably City, and other UK departments, has not had the opportunity to participate in close international cooperation when compared with, for example, departments in the Baltic and Nordic areas [143].

\subsection{Teaching methods}

Odhiambo, Stephens and Goulding [144] comment, based on their analysis of teaching and assessment methods in UK information education, that relatively little has been written about these topics, by comparison with the much more active area of curriculum development. While one reason put forward by these authors, that developing teaching methods is not regarded as 'research', to be put forward to the UK's various research assessment initiatives, the phenomenon seems to be more broadly true over time and internationally than can be accounted for purely in this way. A literature survey [92] found remarkably few accounts of novel teaching methods in areas of information retrieval, information seeking and information organization, topics where one might have expected a variety of novel approaches to be used. Perhaps curriculum development, being often related to a conceptual analysis of a subject discipline, is regarded as more academically interesting and publishable. Or perhaps library/information educators, and students, are conservative in this respect, and have little enthusiasm for novelty in teaching. An interesting example of the introduction of e-learning at another London university, including library/information courses, showed that the initiative was assessed much more favourably by the project team than by the teaching staff and students [145]. It has been noted above that e-learning has been used solely in support of face-to-face classes for City's library/information courses. 
This limited reporting of teaching methods innovation certainly appears to be true of City University's library/information teaching; by comparison with several papers written on City's developing curriculum, only three have any mention of teaching methods: an account of the collaborative development of a system for teaching the creation and use of e-journals [137]; a mention of a project assignment for creating, indexing and searching a computerized database [73]; and an account of the introduction of an e-learning system, serving the library/information courses among others [146]. The first two, having served their purpose, became obsolescent and were discontinued; the latter is now taken for granted as a part of the teaching and learning environment.

And indeed, teaching methods appear to have remained relatively stable over the many years of the City courses. The traditional lecture and seminar/tutorial formats, intended to act as an inspiration and guide to the students' own reading, have been and remain the central method. These have been supported by various forms of individual and group practical work and assignments, often focused on technological systems and environments, and hence changing their nature as the technology changed. Currently successful examples of innovation include the use of Twitter as a 'backchannel' for communication between staff and students, and the use of students' blogs for formative and summative assessment.

As with other issues mentioned in this paper, teaching styles have been subject to swings in fashion. In the memory of the authors, a programme based largely on small group lecturing with nuanced repeats to different groups, e.g. full-time and part-time cohorts, and with minimal supporting, was supplanted, in the name of efficiency, by larger and mixed student groups, supported by extensive online resources. This trend has now gone into reverse, whether towards an optimal solution or to a continued variation cannot yet be stated.

We should recognize, of course, that we have not received students of the 'Google generation', with their perceived requirements for a very different style of teaching and learning [147]; this factor may require major changes in years to come.

Assessment methods have moved from almost complete reliance on formal written examinations to an almost equally complete reliance on individual coursework assignments; see [6] for an overview of developments in assessment in library/information education. These tend to be more popular with students, as being more 'realistic' and potentially relevant to the world of practice; problems of plagiarism, perceived as serious drawbacks to reliance on coursework in other educational settings [148] have not been a major issue for us, as we have tried to construct assignments for which major plagiarism would be difficult, and to change these assignments frequently.

Innovative assessment methods, such as automatic assessment by multiple choice questions, and very large group projects, have been tried from time to time, and generally abandoned as either unpopular with students or unsustainable in the long-term. The use of student blogs as an assessment method is currently our only contribution to innovative assessment.

The input of practitioners as visiting lecturers has been an important feature of the City courses since inception. These have been largely limited to one or two lectures on the visitor's specialty or experience, with the additional use of practitioners as module leaders in the Pharmaceutical Information Management degree. This ‘brief immersion' into teaching, made possible by our London location, means that the students experience a wide range of views, but means that we miss the benefits, as well as the problems, of a more lengthy practitioner input [149, 150].

\section{Conclusions}

Educational programmes evolve over time in response to a variety of internal and external factors; their response is not always entirely rational and rarely entirely successful. No educational programme - certainly not one based in a rapidly changing environment - is ever complete, nor entirely fit for purpose.

This article has shown how the library/information programmes at City University London have adapted, and continue to adapt, to meet changing needs and situations. The lessons learned over this relatively lengthy period should, we hope, be informative and helpful for the development of information education generally. 


\section{Acknowledgements}

We are grateful to Charles Oppenheim for helpful comments and suggestions.

\section{References}

[1] T. Saracevic, An essay on the past and future of information science education - 1: historical overview, Information Processing and Management 15(1) (1979) 1-15.

[2] D.J. Grogan, Education for librarianship: some persistent issues, Education for Information 1(1) (1983) 3-23, reprinted in 25(1), (2007) 5-26.

[3] J. MacDougall and J.M. Brittain, Library and information science education in the United Kingdom, Annual Review of Information Science and Technology 27 (1992) 361-390.

[4] K. Wood, Professional education: historical review. In: J. Elkin and T. Wilson (eds), The Education of Library and Information Professionals in the United Kingdom (Mansell, London, 1997) 1-30.

[5] A.Y. Um and J. Feather, Education for information professionals in the UK, International Information and Library Review 39(3/4) (2007) 260-268.

[6] E.M. Mezick and M.E.D. Koenig, Education for information science, Annual Review of Information Science and Technology 42 (2008) 593-624.

[7] B. Flood, Drexel's Information Science M.S. program, 1963-1971: an insider's recollections, Journal of the American Society for Information Science 51(12) (2000) 1137-1148.

[8] D. Bawden, Information science at City University London, Aslib Proceedings 59(4/5) (2007) 305-306.

[9] P.A. Yates-Mercer, An appreciation of Jason Farradane, Journal of Information Science 15(6) (1989) 305-306.

[10] L. Robinson, Information science: communication chain and domain analysis, Journal of Documentation 65(4) (2009) 578-591.

[11] D. Bawden, Smoother pebbles and the shoulders of giants, Journal of Information Science 34(4) (2008) 415-426.

[12] J. Farradane, Training for information science, Journal of Documentation 26(3) (1970) 261-265.

[13] I. Simpson, Education for information science. 1. The United Kingdom, Journal of Information Science 1(1) (1979) 49-57.

[14] P.A. Yates-Mercer, The academic performance of post-graduate information science students, The Information Scientist 10(1) (1976) 23-38.

[15] J.S. Rennie, A history of the Department of Information Science at the City University, Journal of Information Science 12(1/2) (1986) 3-13.

[16] R.T. Bottle, Education for information and library work, Aslib Proceedings 28(1) (1976) 22-29.

[17] R.T. Bottle, Teaching and research at the City University's Centre for Information Science, Nachrichten fur Dokumentation 32(2) (1981) 60-61.

[18] G.M. Dyson and J.E.L. Farradane, Education in information work: the syllabus and present curriculum of the Institute of Information Scientists Ltd., Journal of Chemical Documentation 2(2) (1962) 74-76.

[19] W.L. Saunders, Library school histories. 4. United Kingdom: The University of Sheffield Postgraduate School of Librarianship and Information Science, International Library Review 3(1) (1971) 97-100.

[20] W.L. Saunders, The University of Sheffield Department of Information Studies, 1964-89, Journal of Information Science 15(4/5) (1989) 193-202.

[21] H. Schur, University of Sheffield M.Sc. course in information studies, Aslib Proceedings 21(1) (1969) 24-31.

[22] F.E. Wood, Scientists in librarianship and information work: a survey of former information studies students of the Postgraduate School of Librarianship and Information Science, University of Sheffield, 1964-1973. Journal of Librarianship 7(1) (1975) 31-48.

[23] T.E. Allibone, Careers in science information work, Bulletin: Institute of Information Scientists 5(2) (1966) 5-12.

[24] W.L. Saunders, The nature of information science, The Information Scientist 8(2) (1974) 57-70

[25] K. McGarry, Education for librarianship and information science: a retrospect and revaluation, Journal of Documentation 39(2) (1983) 95-122.

[26] R.T. Bottle, Education for IS or IT: is there a difference?, Journal of Information Science 8(4) (1984) $167-170$.

[27] C. Oppenheim, The Institute's new criteria for information science, Journal of Information Science 4(5) (1982) 229-234. 
[28] D. Bawden, Health informatics education; an information-related undergraduate perspective, Education for Information 14(1) (1996) 1-6.

[29] A. Dawson and D. Brown, Towards 100 years of educating the information professions at UCL SLAIS, Aslib Proceedings 58(1) (2006) 6-9.

[30] D.E. Weingand, Describing the elephant: what is continuing professional education, IFLA Journal 26(3) (2000) 198-202.

[31] C. Smith, Education and training of information staff - the current position. In: Information for Industry: The Next Ten Years (British Library, London, 1984) 33-42.

[32] C. Urquhart, S. Hornby, T. Rodgers and D. Bawden, The health information practitioner as learner and educator, Education for Information 16(1) (1998) 69-81.

[33] R. Audunson, LIS and the creation of a European educational space, Journal of Librarianship and Information Science 37(4) (2005) 171-174.

[34] B. Badovinac and P. Južnič, Toward library and information science education in the European Union: a comparative analysis of library and information science programmes of study for new members and other applicant countries to the European Union, New Library World 106(3/4) (2005) 173-186.

[35] S. Virkus, Collaboration in LIS education in Europe: challenges and opportunities, presented at 73rd IFLA Congress, Durban, South Africa, August 2007. Available from: http://archive.ifla.org/IV/ifla73/ papers/134-Virkus-en.pdf

[36] P. Vilar and M. Žumer, The Bologna reform at the department of library and information science and book studies, Information Retrieval 12(2) (2009) 102-116.

[37] D. Bawden and L. Robinson, Promoting literacy in a digital age: approaches to training for information literacy, Learned Publishing 15(4) (2002) 297-301.

[38] P. Enser, The role of professional body accreditation in library and information science education in the UK, Libri 52(4) (2002) 214-219.

[39] B. Fisher, G. Hallam and H. Partridge, Different approaches: common conclusions. The skills debate of the twenty-first century, New Review of Academic Librarianship 11(1) (2005) 13-29

[40] CILIP, Body of Professional Knowledge (Chartered Institute of Library and Information Professionals, London, 2004).

[41] B. Hjørland, Domain analysis in information science: eleven approaches - traditional as well as innovative, Journal of Documentation 58(2) (2002) 422-462.

[42] L. Robinson, Teaching reference and information services at City University London, Refer 26(2) (2010) $10-12$.

[43] S.E. Robertson, B.C. Brookes and information science education: a personal view, Journal of Information Science 16(1) (1990) 9-10.

[44] W.Y. Arms, Information science as a liberal art, Interlending and Document Supply 33(2) (2005) 81-84

[45] M. Buckland, The 'liberal arts' of library and information science and the research university environment. In: P. Ingwersen and N.O. Pors (eds), Proceedings of the Second International Conference on Conceptions of Library and Information Science: Integration in Perspective (Royal School of Librarianship, Copenhagen, 1996) 75-84.

[46] M. Gorman, Whither library education?, New Library World 105(9/10) (2004) 376-380

[47] D. Bawden, Organized complexity, meaning and understanding: an approach to a unified view of information, Aslib Proceedings 59(4/5) (2007) 307-327.

[48] Association of Assistant Librarians, Which library school? (Association of Assistant Librarians, London, 1984).

[49] B. Cronin, Information science in the international arena: an educator's perspective, Aslib Proceedings44(4) (1992) 195-202.

[50] R. Audunson, Library and information science education: discipline, profession, vocation?, Journal of Education for Library and Information Science 48(2) (2007) 94-107

[51] A. Brine and J. Feather, Supporting the development of skills for information professionals, Education for Information 20(3/4) (2002) 253-262.

[52] D. Bawden, Facing the education future: CoLIS 6 Educational Forum, Information Research 12(4) (2007).

[53] B. Cronin, An I-dentity crisis? the information schools movement, International Journal of Information Management 25(4) (2005) 363-365.

[54] L.J.Bonnici, M.M. Subramanian and K. Burnett, Everything old is new again: the evolution of library and information science education from LIS to iField, Journal of Education for Library and Information Science 50(4) (2009) 263-274.

[55] D.P. Wallace, The iSchools, education for librarianship and the voice of doom and gloom, Journal of Academic Librarianship 35(5) (2009) 405-409. 
[56] Transbinary Group on Librarianship and Information Studies, Report of the Transbinary Group on Librarianship and Information Studies (British Library, London, 1986).

[57] B. Cronin, The education of library-information professionals: a conflict of objectives? Aslib Occasional Papers No. 28 (Aslib, London, 1982).

[58] M.B. Line, Requirements for library and information work and the role of library education, Education for Information 1(1) (1983) 25-37.

[59] L. Ashcroft, Developing competencies, critical analysis and personal transferable skills in future information professionals, Library Review 53(2) (2004) 82-88.

[60] A. Colley, Taking a skills-based approach to the future, Library and Information Update 9(6) (2010) 23.

[61] M. Roggema-van Heusden, The challenge of developing a competence-oriented curriculum: an integrative framework, Library Review 53(2) (2004) 98-103.

[62] A. Goulding and B. Usherwood, Research-led teaching in librarianship and information studies, Journal of Librarianship and Information Science 35(3) (2003) 137-139.

[63] J. Borup Larsen, A survey of library and information science schools in Europe. In: L. Kajberg and L. Lørring (eds), European Curriculum Reflections on Library and Information Science Education (Royal School of Library and Information Science, Copenhagen, 2005) 232-242.

[64] E. Ansell, B. Sen and C. Watts, Library school placements in the health sector: a positive experience at Liverpool John Moores University, United Kingdom, Health Information and Libraries Journal 21(2) (2004) 125-128

[65] B. Chivers, K. Flatten, C. Nankivell and B. Reid, The Value of LIS School Work Placements, BLRD Report No. 6222 (British Library Research And Development Department, London, 1995).

[66] J. Rowley, Work-based projects, Education for Information 17(3) (1999) 245-251.

[67] A.R. Blick, Information science research versus the practitioner, Nachrichten fur Dokumentation 34(6) (1983) 261-265.

[68] V. Rosenberg, The teaching of information science to non-scientists, Journal of Education for Librarianship 13(2) (1972) 94-103.

[69] P. Ingwersen, The human approach to information science and management: the framework and prospects underlying the new Danish MSc programme, Journal of Information Science 20(3) (1994) 197-208.

[70] T. Petrinic and C. Urquhart, The education and training needs of health librarians - the generalist versus specialist dilemma, Health Information and Libraries Journal 24(3) (2007) 167-176.

[71] K.J. McGarry, Undergraduate degrees in information and library studies: a retrospect and revaluation, Education for Information 15(2) (1997) 105-123.

[72] A. Goulding, The future of undergraduate librarianship degrees, Journal of Librarianship and Information Science 33(4) (2001) 165-167.

[73] M. Beaulieu, Developing the information professional: whose responsibility?, Impact: Journal of the Career Development Group (CILIP) 1(7) (1998) 107-112.

[74] J.H.E. van der Starre, Short report on library and information science education in the Netherlands and Belgium (Flanders), Libri 40(2) (1990) 158-164.

[75] M.L. Rice-Lively, Schools of information and undergraduate education, Bulletin of the American Society for Information Science and Technology 36(4) (2010) 12-13.

[76] B. Loughridge, Life after Sheffield: follow-up studies of Masters graduates, Journal of Librarianship and Information Science 35(3) (2003) 165-170.

[77] J.G. Marshall, V.W. Marshall, J.C. Morgan, D. Barreau, B.B. Moran, P. Solomon, S. Rathbun-Grubb and C.A. Thompson, Where are they now? Results of a career survey of library and information science graduates, Library Trends 58(2) (2009) 141-154.

[78] T.L. Weech and A.M. Konieczny, Alternative careers for graduates of LIS schools: the North American perspective - an analysis of the literature, Journal of Librarianship and Information Science 39(2) (2007) 67-78.

[79] M. Kinnell, From autonomy to systems: education for the information and library professions 1986-1999, Journal of Documentation 56(4) (2000) 399-411.

[80] M. Huckle, Driving change in the profession: subject benchmarking in UK library and information management, Libri 52(4) (2002) 209-213.

[81] J. Morgan and D. Bawden, Teaching knowledge organisation: educator, employer and professional association perspectives, Journal of Information Science 32(2) (2006) 108-115.

[82] F.W. Lancaster, The curriculum of information science in developed and developing countries, Libri 44(3) (1994) 201-205.

[83] R. Grover, H. Achleitner, N. Thomas, R. Wyatt and F.N. Vowell, The wind beneath our wings: chaos theory and the butterfly effect in curriculum design, Journal of Education for Library and Information Science 38(4) (1997) 268-282. 
[84] R. Missingham, Library and information science: skills for twenty-first century professionals, Library Management 27(4) (2006) 257-268.

[85] T.D. Wilson, Mapping the curriculum in information studies, New Library World 102(11/12) (2001) 436-442.

[86] J. Bronstein, Current trends in library and information studies curricula, Libri 59(2) (2009) 78-87.

[87] G.A. Marco, The demise of the American core curriculum, Libri 44(3) (1994) 175-189.

[88] J. Raju, The 'core' in library and/or information science education and training, Education for Information 21(4) (2003) 229-242.

[89] R.A. Hall, Exploring the core: an examination of required courses in ALA-accredited programs, Education for Information 27(1) (2009) 57-68.

[90] L. Lørring, Didactical models behind the construction of an LIS curriculum, Journal of Education for Library and Information Science 48(2) (2007) 82-93.

[91] E. Daniel, S. Lazinger and O. Harbo, Guidelines for professional library/information educational programs - 2000, International Federation of Library Associations, Education and Training Section, available from www.ifla.org/en/publications/guidelines-for-professional-libraryinformation-educationalprograms-2000

[92] D. Bawden, Information seeking and information retrieval: the core of the information curriculum, Journal of Education for Library and Information Science 48(2) (2007) 125-138.

[93] D. Bawden, Brian Vickery and the uneasy information scientists, Journal of Documentation 66(3) (2010) 305-306.

[94] M. Gerolimos, Skills developed through library and information science education, Library Review 58(7) (2009) 527-540.

[95] J.H.E.van der Starre, Library schools and information technology: a European overview, Information Processing and Management 29(2) (1993) 241-247.

[96] A. Poulter and D. McMenemy, Beyond the European Computer Driving Licence: basic and advanced ICT skills for the new library practitioner, IFLA Journal 30(1) (2004) 37-46.

[97] M. Freeman and J. Rowley, An information systems approach to teaching IT skills to students of library and information studies, Education for Information 14(3) (1996) 233-237.

[98] M. Farkas, Training librarians for the future: integrating technology into LIS education. In: R.S. Gordon (ed.), Information Tomorrow: Reflections of Technology and the Future of Public and Academic Libraries (Information Today, Medford, NJ, 2007) 193-202.

[99] D. Bawden, P. Vilar, J. Bates, I. Cordeiro, J. Steinerova and P. Vakkari, Europe-wide training programmes for information retrieval and information seeking, Proceedings of Online Information 2005 (Learned Information Europe, London, 2005) 143-148.

[100] D. Bawden, J. Bates, J. Steinerova, P. Vakkari and P. Vilar, Information retrieval curricula: contexts and perspectives. In: MacFarlane, A. (ed.), Proceedings of the First International Workshop on Teaching and Learning in Information Retrieval (British Computer Society, London, 2007) 55-60.

[101] T. Koltay and I. Boda, Digital library issues in Hungarian LIS curricula: examples from three library schools, Library Review 57(6) (2008) 430-441.

[102] J. Pomerantz, S. Oh, S. Yang, E.A. Fox and B.M. Widemouth, The core: digital library education in library and information science programs, D-Lib Magazine 12(11) (2006) available from www.dlib.org/dlib/ november06/pomerantz/11pomerantz.html

[103] A. Poulter and R. Brunt, On reading 'information storage and retrieval in the professional curriculum' by Rodney Brunt, Library Review 56(7) (2007) 557-562.

[104] A.M. Tammaro, A curriculum for digital libraries: a reflection on the European debate, New Library World 108(5) (2007) 229-246.

[105] P. Vilar, M. Žumer and J. Bates, Information seeking and information retrieval curricula development for modules taught in two library and information science schools: the cases of Ljubljana and Dublin, Information Research 12(4) (2007).

[106] D. Bawden, P. Vilar and V. Zabukovec, Education and training for digital librarians: a Slovenia/UK comparison, Aslib Proceedings 57(1) (2005) 85-98.

[107] M. Gorman, Why teach cataloguing and classification?, Cataloguing and Classification Quarterly 34(1/2) (2002) 1-13.

[108] K.W. Moss, Swings and roundabouts: the role of cataloguing and classification in the LIS curriculum, Catalogue and Index 155 (2007), 2-5.

[109] I. Hsieh-Yee, Educating cataloguing professionals in a changing information environment, Journal of Education for Library and Information Science 49(2) (2008) 93-106. 
[110] M. Hudon, Teaching classification, 1990-2010, Cataloguing and Classification Quarterly 48(1) (2010) 64-82.

[111] S.D. Hall-Ellis, Cataloguer competences ... What do employers require?, Cataloguing and Classification Quarterly 46(3) (2008) 305-330.

[112] A. Danskin, Swings and roundabouts: British Library perspective, Catalogue and Index 155 (2007) 9-10.

[113] H. Jardine, 'Recruiting the attitude': a pubic library viewpoint, Catalogue and Index 155 (2007) 10-11.

[114] E. Maceviciute, Information management in the Baltic, Nordic and UK LIS schools, Library Review 51(3/4) (2002) 190-199.

[115] G. Walton, A. Goulding and D. Stephens, Future leaders: what do they think? In: J. Varlejs, L. Lewis and G.Walton (eds), Strategies for Regenerating the Library and Information Professions (de Gruyter/K.G. Saur, Berlin, 2009) 202-214.

[116] A. Morris, Provision of research methods teaching in UK LIS departments, New Library World 107(3/4) (2006) 116-126.

[117] N.O. Pors, Information retrieval, experimental methods and statistical analysis, Journal of Documentation 56(1) (2000) 55-70.

[118] M. Seadle, Education for twenty-first century librarians, Library Hi Tech 22(4) (2004) 337-339.

[119] P. Južnič and J. Urbana, Developing research skills in library and information science studies, Library Management 24(6/7) (2003) 324-331.

[120] S. Corrall, Teaching reference and information services at Sheffield iSchool, Refer 26(1) (2010) 10-14.

[121] T. Carbo and S. Almagno, Information ethics: the duty, privilege and challenge of educating information professionals, Library Trends 49(3) (2001) 510-518.

[122] E.A. Buchanan, Ethics in library and information science: what are we teaching, Journal of Information Ethics 13(1) (2004) 51-60.

[123] B. McKee and M. Huckle, Modern professionalism: a mix of knowledge, skills and ethics, Library and Information Update 8(4) (2009) 19-21.

[124] J.S. Rennie, Education and training in business information at the City University, Business Information Review 2(2) (1985) 22-29.

[125] J.S. Rennie, Training in business information - what the practitioners want, Business Information Review 3(2) (1986) 24-38.

[126] J. Cummins and D. Bawden, Accounting for information: information and knowledge in the annual reports of FTSE 100 companies, Journal of Information Science 36(3) (2010) 283-305.

[127] L. Robinson, Understanding Healthcare Information (Facet, London, 2010).

[128] D. Bawden and L. Robinson, Pharmaceutical information; a 30-year perspective on the literature, Annual Review of Information Science and Technology (2010).

[129] T.S. Eisenschitz, The student research programme into patent information at the City University, London, World Patent Information 6(3) (1984) 108-114.

[130] J. Rennie, Learning how to help the citizen, Library Association Record 83(7) (1981) 335, 353.

[131] A.S. Duff, The status of information society studies in the information science curriculum, Library Review 51(3/4) (2002) 139-148.

[132] I. Abdullahi, L. Kajberg and S. Virkus, Internationalization of LIS education in Europe and North America, New Library World 108(1/2) (2007) 7-24.

[133] T. Weller, Information history: its importance, relevance and future, Aslib Proceedings 59(4/5) (2007) 437-448.

[134] C. Pawley, History in the library and information science curriculum: outline of a debate, Libraries and Culture 40(3) (2005) 223-238.

[135] A. Hannan and H. Silver, On being an external examiner, Studies in Higher Education 31(1) (2006) 57-69.

[136] Higher Education Academy (UK), Subject centres, available from www.heacademy.ac.uk/subjectcentres, accessed 6 March 2010

[137] J. Meadows, P.A. Yates-Mercer and D. McVey, The training of library and information staff in the handling of online electronic journals, Journal of Information Science 23(2) (1997) 163-167.

[138] L. Kajberg, The European LIS curriculum project: an overview, Journal of Education for Library and Information Science 48(2) (2007) 68-81.

[139] L. Lørring, European LIS curriculum project: content, reflections and curricular questions, Bulletin of the American Society for Information Science and Technology 33(2) (2007) 16-20.

[140] D. Bawden, L. Robinson, T. Anderson, J. Bates, U. Rutkauskiene and P. Vilar, Towards Curriculum 2.0: library/information education for a Web 2.0 world, Library and Information Research 31(99) (2007) 14-25.

[141] L. Kajberg, A survey of internationalisation activities in European library and information science schools, New Review of Information and Library Research 9 (2003) 25-60. 
Lyn Robinson and David Bawden

[142] L. Kajberg, Cross-country partnerships in international library and information science education, New Library World 104(6) (2003) 218-226.

[143] S. Virkus and O. Harbo, The internationalisation of Baltic Library and Information Science education with emphasis on the cooperation with Nordic partners, Education for Information 20(3/4) (2002) 217-235.

[144] F. Odhiambo, D. Stephens and A. Goulding, Teaching and assessment methods in UK information science: a ten year review of professional and scholarly journal content and predictions for 2011, Education for Information 20(3/4) (2002) 183-198.

[145] P. Williams and S. Quinsee, Using WebCT to teach key skills, Library and Information Update 2(2) (2003) 42-43.

[146] S. Quinsee and P. Williams, Delivering Masters online, Library and Information Update 2(2) (2003) 48-49.

[147] D. Nicholas, B. Gunter and I. Rowlands, The Google Generation: are ICT Innovations Changing Information Seeking Behaviour? Information Search Behaviour Developments and the Future Learner (Chandos, Oxford, 2009).

[148] S. Dahl, Turnitin: the student perspective on using plagiarism detection software, Active Learning in Higher Education 8(2) (2007) 173-191.

[149] R. Barlow and A. Green, Practitioners as lecturers: benefits, advantages and practicalities, Journal of Librarianship 18(3) (1986) 165-179.

[150] M. Heery, Practitioners as educators: the Bristol MSc in Information and Library Management, Library Review 48(3/4) (1999) 120-130. 